\title{
IDENTIFICATION OF SALMONELLAE OF SEROGROUP C1 BY IMMUNOFLUORESCENCE AND CO-AGGLUTINATION WITH ANTISERUM AGAINST AN OLIGOSACCHARIDE-PROTEIN CONJUGATE
}

\author{
E. Ekwall**, S. B. Svenson and A. A. Lindberg \\ Department of Bacteriology, National Bacteriological Laboratory, S-105 21 Stockholm \\ and ${ }^{*}$ Department of Infectious Diseases, Roslagstull Hospital, \\ Box 5901, S-114 89 Stockholm, Sweden
}

\begin{abstract}
Summary. Antiserum specific for salmonella $\mathrm{O} 7$ antigen was raised by immunisation of rabbits with an artificial conjugate consisting of oligosaccharide and bovine serum albumin (Os-BSA). The oligosaccharide was a pentasaccharide isolated after cleavage of the $\mathrm{O}$ antigen polysaccharide chain of Salmonella thompson $(\mathrm{O}$ antigen 6,7$)$ with endo-glycanase from bacteriophage 14 . The usefulness of the $S$. thompson Os-BSA antiserum for rapid and accurate identification of isolates of Salmonella of serogroup $\mathrm{Cl}(\mathrm{O} 6,7)$ was shown by indirect immunofluorescence tests in which 77 strains of Salmonella of serogroup $\mathrm{C} 1$ were correctly identified from among 848 intestinal strains investigated. The finding that three strains of Escherichia coli and most strains of Candida were also positive in immunofluorescence tests with this antiserum is readily explained by the known structural similarities among the antigenic determinants of E. coli, Candida and Salmonella of serogroup $\mathrm{C}$. The specificity of the antiserum for the $\mathrm{O} 7$ antigen determinant was further demonstrated in enzyme-linked immunosorbent assay tests and in co-agglutination tests with staphylococci sensitised with $S$. thompson Os-BSA antiserum.
\end{abstract}

\section{INTRODUCTION}

Because identification of salmonellae is based on conventional cultural procedures and biochemical and serological tests, which are time consuming and expensive, there is a need for diagnostic tools that are rapid, accurate and cheap. In this respect, other systems such as immunofluorescence (IFL) and co-agglutination (COA) have been investigated (Cherry and Moody, 1965; Kronvall, 1973; Thomason and Hebert, 1974; Cherry et al., 1975). However, their diagnostic potential is highly dependent on the specificity of the antibody preparations used; the lack of specificity of many conventional antisera, i.e., those raised against whole killed bacteria, has limited their use in these alternative methods (Thomason and Hebert, 1974). 
Classification of salmonellae into serogroups is based on the specificity of their $\mathrm{O}$ antigens (Kauffmann, 1966), the determinants of which reside in the polysaccharide chain of the cell-wall lipopolysaccharide (LPS). The $O$ polysaccharide chains of salmonellae from serogroups A (O antigens 1, 2, 12), B (O1, 4, (5), 12), C2 (O6, 8), C3 $(\mathrm{O} 8,20), \mathrm{D}(\mathrm{O} 1,9,12)$ and $\mathrm{El}-4(\mathrm{O} 3,10 ; \mathrm{O} 3,15 ; \mathrm{O} 3,34 ; \mathrm{O} 1,3,19)$ are polymers of oligosaccharide-repeating units comprising from three to five monosaccharide residues (Kenne and Lindberg, 1982). We have reported elsewhere the preparation of a series of synthetic disaccharide-bovine serum albumin (BSA) conjugates, representative of $\mathrm{O}$ antigens 2, 4, 8 and 9, that elicited antisera specific for their respective bacterial $\mathrm{O}$ antigens and were of use, therefore, in identification by IFL and COA techniques (Svenungsson and Lindberg, 1977, 1978 $a$ and $b, 1979$; Svenungsson, Jörbeck and Lindberg, 1979). Although $75 \%$ of the salmonellae isolated in Sweden are of serogroup $\mathrm{B}, \mathrm{C} 2, \mathrm{C} 3$ or $\mathrm{D}$, about $15 \%$ belong to serogroup $\mathrm{C} 1(\mathrm{O} 6,7)$. However, because the structure of the polysaccharide chain that determines the $\mathrm{O}$ antigenic specificity of salmonellae of serogroup $\mathrm{Cl}$ has not been definitively established (Fuller and Staub, 1968), the use a defined antigenic determinant as hapten in an artificial immunogen was not possible. A series of oligosaccharides has been isolated from the $\mathrm{O}$ polysaccharide of Salmonella thompson strain IS40 (O6 $\left.6_{1}, 6_{2}, 7\right)$ (Bruse, Wrangsell, Lönngren and Svenson, unpublished results). In this paper, we describe an antiserum with specificity for antigen 07 , prepared against one of these oligosaccharides covalently coupled with BSA, and discuss its usefulness for the identification of isolates of salmonellae of serogroup $\mathrm{Cl}$ by IFL and COA tests.

\section{MATERIALS AND METHODS}

Bacterial and yeast strains. S. cholerae-suis strain 5210 was kindly provided by Dr L. Le Minor, Institut Pasteur, Paris. Other strains of bacteria were from the culture collection of the Department of Bateriology, National Bacteriological Laboratory, Stockholm, or were fresh cultures isolated from faeces in the course of examination for pathogenic intestinal bacteria. The isolation and identification of the different bacteria were performed as described by Svenungsson et al. (1979). Staphylococcus aureus strain Cowan 1 was used for the preparation of the COA reagent. Candida albicans (ATCC2091), C. curvata (ATCC10567), C. pseudotropicalis (PHLS3106), C. zeylanoides (ATCC7351), C. tropicalis (ATCC750), C. guilliermondi (ATCC6260), C. stellatoidea (ATCC11006), C. parapsilosis (ATCC7330) and C. krusei (ATCC6258) were from the mycology culture collection of the National Bacteriological Laboratory, Stockholm.

Bacteriophage 14 was kindly provided by Dr L. Le Minor, Institut Pasteur, Paris.

Lipopolysaccharide preparations from $S$. typhimurium strain $\mathrm{SH} 4809(\mathrm{O} 4,5,12)$ and the rough strain TV160 were available from other studies (Svenson and Lindberg, 1979); those from $S$. thompson strain IS40 $\left(\mathrm{O6}_{1}, 6_{2}, 7\right), S$. cholerae-suis strain $5210\left(\mathrm{O6}_{2}, 7\right)$ and $S$. newport strain IS50 $\left(\mathrm{O6}_{1}, 8\right)$ were prepared as described by Hellerqvist et al. (1968).

Preparation of 'oligosaccharides. Oligosaccharides from $S$. thompson strain IS40 were prepared as follows (Bruse, Wrangsell, Lönngren and Svenson, unpublished results): LPS from $S$. thompson was treated with $0.15 \mathrm{M} \mathrm{NaOH}$ at $100^{\circ} \mathrm{C}$ for $60 \mathrm{~min}$. After extraction of released fatty acids, the residual solution was centrifuged at $5000 \mathrm{~g}$ for $20 \mathrm{~min}$ and the clear supernate was extensively dialysed against $5 \mathrm{~mm}$ ammonium carbonate buffer $(p \mathrm{H} \mathrm{7.0)}$. The mixture of oligosaccharides obtained after treatment of the $\mathrm{O}$ polysaccharide with endo-mannosidase from bacteriophage 14 (specific for bacteria of serogroup C1) was separated on Bio-Gel P4 (Bio Rad Laboratories, Richmond, Calif).

Oligosaccharide-bovine serum-albumin conjugate. An oligosaccharide of mol. wt c. 850 was covalently coupled to BSA as described by Svenson and Lindberg (1979) and the resulting conjugate, containing oligosaccharide and BSA in a molar ratio of $c .10: 1$, is referred to as $S$. thompson Os-BSA. 
Immunisation procedure. The $S$. thompson Os-BSA conjugate suspended in Freund's complete adjuvant $(1: 1)$ was injected in $50-\mu \mathrm{g}$ amounts directly into the popliteal lymph nodes of rabbits on days $1,15,56$ and 71 . Rabbits were bled before injection and at day 85 .

Enzyme-linked immunosorbent assay (ELISA). Performance of the ELISA test and preparation of the sheep anti-rabbit immunoglobulin alkaline-phosphatase conjugate specific for rabbit immunoglobulins IgG, IgM and IgA followed the techniques of Carlsson, Hurvell and Lindberg (1976).

Antiserum against the Salmonella $\mathrm{O} 9$ determinant, i.e., 3-O- $\alpha$-(tyvelopyranosyl)- $\alpha$-D-mannopyranoside covalently linked to BSA, was available from another investigation (Svenungsson and Lindberg, 1977). Antiserum against salmonella factor O7, prepared according to the method of Kauffmann (1966), was used in slide agglutination tests.

Co-agglutination studies. The preparation of staphylococci sensitised with $S$. thompson Os-BSA antiserum has been described (Svenungsson and Lindberg, 1978b). The COA reagent was stable for at least 2 weeks when stored at $4^{\circ} \mathrm{C}$. A few bacterial colonies from the culture under investigation were suspended in a drop of the COA reagent on a glass slide, which was rocked back and forth for 2 min. Agglutination clearly visible by the naked eye was registered as $2+$ and, when a magnifying glass was needed for its observation, as $1+$.

Immunofluorescence studies. The indirect IFL method was that of Svenungsson and Lindberg (1977). The sheep anti-rabbit immunoglobulin-fluorescein isothiocyanate conjugate (fluorescein:protein molar ratio of 2.2:1) was from the Department of Immunology, National Bacteriological Laboratory, Stockholm. The working dilution of the conjugate was the highest dilution ( 1 in 40$)$ that gave a $4+$ reaction. A Leitz Orthoplan fluorescence microscope with incident light and a mercury HBO-200 lamp as light source was used. Fluorescence reactions were graded as described by Karlsson, Thore and Kudynowski (1975); $4+$ and $3+$ reactions were judged as positive, and $2+$ and $1+$ reactions as negative. In the performance of the IFL tests, the identity of a strain was not known to the examiner.

\section{RESULTS}

The specificity of the antiserum raised in rabbits against the $S$. thompson Os-BSA conjugate was first evaluated by ELISA (table I), which indicated a 400-fold increase in titre of a hyperimmune serum against LPS of $S$. cholerae-suis strain $5210\left(\mathrm{O6}_{2}, 7\right)$ and no significant increase in titre against LPS from $S$. newport $\left(\mathrm{O6}_{1}, 8\right)$. This finding suggested that the antibodies elicited were directed against the $\mathrm{O} 7$ antigen determinant. There was no increase in titre against LPS from two heterologous strains of $S$. typhimurium.

TABLE I

ELISA titration of rabbit antiserum elicited against $S$. thompson $O s-B S A$ conjugate

\begin{tabular}{l|cc}
\hline $\begin{array}{c}\text { Lipopolysaccharide } \\
\text { coating antigen } \\
\text { from strain } \\
\text { (O antigens) }\end{array}$ & $\begin{array}{c}\text { ELISA titre* } \\
\text { preimmune } \\
\text { serum }\end{array}$ & $\begin{array}{c}\left(10^{3}\right) \text { of } \\
\text { immune } \\
\text { serum }\end{array}$ \\
\hline $\begin{array}{l}\text { S. cholerae-suis } 5210\left(\mathrm{O6}_{2}, 7\right) \\
\text { S. newport } \text { IS50 }\left(\mathrm{O6} 6_{1}, 8\right)\end{array}$ & 4 & 1590 \\
S. typhimurium SH4809 $(\mathrm{O} 4,12)$ & $<1$ & 7 \\
S. typhimurium TV161 & $<1$ & $<1$ \\
\hline
\end{tabular}

* The serum dilution giving a change in optical density $(400 \mathrm{~nm})$ of $0 \cdot 1$ "per" $100 \mathrm{~min}$. 


\section{Indirect immunofluorescence studies}

In tests with $S$. cholerae-suis strain IS36 $\left(\mathrm{O6}_{2}, 7\right)$, the endpoint titre of two hyperimmune sera from different rabbits that gave a 3+ reaction was 160 . Fluorescence was not obtained in tests with salmonellae of serogroups other than $\mathrm{Cl}$, even when the serum was used at a dilution of 1 in 5 . Neither preimmunisation sera nor serum against BSA gave fluorescence with any strain of $S$. cholerae-suis.

Known salmonellae. The specificity of the $S$. thompson Os-BSA antiserum indicated in ELISA tests was confirmed in IFL tests with 243 strains of Salmonella of known serogroups (table II), most of which were of commonly isolated serogroups. Of

TABLE II

Indirect immunofluorescence with $S$. thompson $O s-B S A$ antiserum by salmonellae of different $O$ serogroups

\begin{tabular}{|c|c|}
\hline $\begin{array}{l}\text { Salmonella } \\
\text { serogroup } \\
\text { (O antigens) }\end{array}$ & $\begin{array}{l}\text { Number of strains positive } \\
\text { by immunofluorescence/ } \\
\text { number of strains tested }\end{array}$ \\
\hline $\begin{array}{l}\mathrm{A}(\mathrm{O} 1,2,12) \\
\mathrm{B}(\mathrm{O} 1,4,5,12) \\
\mathrm{C} 1(\mathrm{O} 6,7) \\
\mathrm{C} 2(\mathrm{O} 6,8) \\
\mathrm{C} 3(\mathrm{O} 8,20) \\
\mathrm{D}(\mathrm{O} 1,9,12) \\
\mathrm{E} 1-4(\mathrm{O} 3,10 ; \mathrm{O} 3,15 ; \\
\quad \quad \mathrm{O} 3,34 ; \mathrm{O} 1,3,19) \\
\mathrm{G} 2(\mathrm{O} 13,23) \\
\mathrm{K}(\mathrm{O} 18) \\
\mathrm{O} 38 \quad \\
\text { O51 }\end{array}$ & $\begin{array}{l}0 / 2 \\
0 / 117 \\
49 / 50 \\
0 / 34 \\
0 / 5 \\
1 / 19 \\
0 / 10 \\
0 / 3 \\
0 / 1 \\
0 / 1 \\
0 / 1 \\
50 / 243\end{array}$ \\
\hline
\end{tabular}

the 50 isolates of serogroup $\mathrm{Cl}$ tested, 49 fluoresced strongly with the antiserum against $S$. thompson Os-BSA (table II); the exceptional strain, $S$. bareilly $(\mathrm{O} 6,7)$, which was scored as negative or weakly positive at the working dilution of serum, was strongly positive in tests with serum at a dilution of 1 in 20 . One isolate, $S$. panama $(\mathrm{O} 1,9,12)$ from serogroup $\mathrm{D}$, was positive in similar tests (see below). The other 192 strains of Salmonella tested gave negative reactions in IFL tests with $S$. thompson Os-BSA serum.

Unidentified intestinal bacteria from faeces. The investigation was extended to include tests with cultures of 324 unidentified enterobacterial strains freshly isolated from faeces (table III). Part of a colony, considered presumptively on morphological grounds to be Salmonella, from a culture on either a deoxycholate-citrate agar or a brilliant green-phenol red agar, was suspended in phosphate-buffered saline on a glass slide for investigation by immunofluorescence. Part of the same colony was examined by routine biochemical and serological tests. Of the 324 strains tested, 27 that fluoresced strongly were salmonellae of serogroup $\mathrm{Cl}(\mathrm{O} 6,7)$; another 214 strains of Salmonella from serogroups other than $\mathrm{C} 1$ and 83 strains of other enterobacteria, primarily isolates of Citrobacter and Enterobacter, were negative (table III). 
TABLE III

Indirect immunofluorescence with $S$. thompson $O s-B S A$ antiserum by enterobacteria isolated from faeces

\begin{tabular}{|c|c|}
\hline $\begin{array}{l}\text { Salmonella serogrup } \\
(0 \text { antigens }) / \\
\text { number of serotypes }\end{array}$ & $\begin{array}{l}\text { Number of strains positive } \\
\text { by immunofluorescence/ } \\
\text { number of strains tested }\end{array}$ \\
\hline $\begin{array}{l}\mathrm{B}(\mathrm{O} 1,4,5,12) / 10 \\
\mathrm{C} 1(\mathrm{O} 6,7) / 7 \\
\mathrm{C} 2(\mathrm{O} 6,8) / 4 \\
\mathrm{D}(\mathrm{O} 1,9,12) / 2 \\
\mathrm{E} 1(\mathrm{O} 3,10) / 1 \\
\mathrm{E} 4(\mathrm{O} 1,3,19) / 1 \\
\mathrm{G} 1(\mathrm{O} 13,22) / 1 \\
\mathrm{P}(\mathrm{O} 38) / 1 \\
\text { Not salmonella }\end{array}$ & $\begin{array}{l}0 / 113 \\
27 / 27 \\
0 / 46 \\
0 / 48 \\
0 / 3 \\
0 / 2 \\
0 / 1 \\
0 / 1 \\
0 / 83\end{array}$ \\
\hline All & $27 / 324$ \\
\hline
\end{tabular}

Intestinal bacilli. The specificity of the antiserum against $S$. thompson Os-BSA was further assessed in tests with 364 isolates of intestinal bacilli (table IV). Apart from three strains of $E$. coli, all other enterobacteria and all strains of Pseudomonas, Aeromonas, Acinetobacter, Vibrio, Pasteurella and Bacteroides tested were negative in the IFL test. Of the three strains of $E$. coli that were positive in the IFL test, one belonged to serogroup O112ab; the other two were not typable.

Candida strains. Because cross reactions between salmonellae of serogroup C1 and strains of Candida are well known, isolates of nine different species of Candida were assayed in IFL tests with $S$. thompson Os-BSA antiserum. Apart from the isolate

TABLE IV

Indirect immunofluorescence with S. thompson Os-BSA antiserum of intestinal bacilli other than salmonellae

\begin{tabular}{l|c}
\hline & $\begin{array}{c}\text { Number of strains* positive } \\
\text { by immunofluorescence/ } \\
\text { number of strains tested }\end{array}$ \\
\hline Species or group & $3 / 104$ \\
\hline Escherichia coli & $0 / 78$ \\
Enterobacter spp. & $0 / 35$ \\
Citrobacter spp. & $0 / 28$ \\
Proteus spp. & $0 / 19$ \\
Klebsiella spp. & $0 / 15$ \\
Shigella spp. & $0 / 5$ \\
Yersinia enterocolitica & $0 / 2$ \\
Serratia spp. & $0 / 6$ \\
Aeromonas spp. & $0 / 7$ \\
Pseudomonas spp. & $0 / 2$ \\
Acinetobacter spp. & $0 / 4$ \\
Vibrio spp. & $0 / 1$ \\
Pasteurella spp. & $0 / 58$ \\
Bacteroides spp. & $3 / 364$ \\
\multicolumn{1}{c}{ All } & \\
\hline
\end{tabular}

* Includes 83 strains of enterobacteria from table III 
of $C$. curvata, strains of Candida were strongly positive. However, the possibility of misidentification of Candida as Salmonella is unlikely in view of major differences in their shape and size.

\section{Co-agglutination}

The applicability of COA was investigated in tests with 129 strains of Salmonella from serogroups A to E and O35. Each of the 22 isolates of Salmonella from serogroup $\mathrm{C} 1$ agglutinated strongly with the $S$. thompson Os-BSA antiserum-sensitised reagent (table V). Another 107 strains from serogroups other than $\mathrm{Cl}$ were negative.

TABLE V

Co-agglutination of salmonellae with $S$. thompson Os-BSA antiserum-sensitised staphylococci

\begin{tabular}{l|c}
\hline $\begin{array}{l}\text { Salmonella } \\
\text { serogroup } \\
\text { (O antigens) }\end{array}$ & $\begin{array}{c}\text { Number of strains positive } \\
\text { by co-agglutination/ } \\
\text { number of strains tested }\end{array}$ \\
\hline A $(\mathrm{O} 1,2,12)$ & $0 / 5$ \\
B (O1, 4, 5, 12) & $0 / 58$ \\
C1 (O6,7) & $22 / 22$ \\
C2 (O6, 8) & $0 / 12$ \\
C3 (O8, 20) & $0 / 6$ \\
D (O1, $(01,12)$ & $0 / 18$ \\
E1 (O3,10) & $0 / 1$ \\
E4 (O13, 19) & $0 / 6$ \\
O35 & $0 / 1$ \\
\multicolumn{1}{c}{ All } & $22 / 129$ \\
\hline
\end{tabular}

\section{DISCUSSION}

The pentasaccharide from LPS of $S$. thompson $\left(\mathrm{O6}_{1}, 6_{2}, 7\right)$, used as hapten in covalent linkage to an immunogenic carrier protein, apparently elicited antibodies specific for antigen $\mathrm{O} 7$ as demonstrated in ELISA, IFL and COA tests. Most of the information was obtained from IFL studies, which showed that among 848 isolates of intestinal bacteria, 76 of 77 strains of Salmonella of serogroup C1 were correctly identified at the routine working dilution of serum. In view of our previous observations (Svenungsson and Lindberg, 1977, 1978 $a$ and $b$ ) that strains after storage often gave weaker reactions in IFL tests than those of fresh clinical isolates, it was not unexpected that the exceptional strain of serogroup $\mathrm{C} 1$ that gave anomalous results in IFL tests was an isolate of $S$. bareilly from a stock-culture collection.

An unexpected positive reaction in IFL tests with the $S$. thompson Os-BSA antiserum was given by an isolate of $S$. panama $(\mathrm{O} 9,12)$. However, the finding that the bacterial cells from that group-D culture that stained with antiserum specific for antigen $O 9$ outnumbered those stained with the $S$. thompson antiserum by 100 to 1 suggested that the culture of $S$. panama was possibly contaminated with small numbers of salmonellae of serogroup $\mathrm{Cl}$ (which we have not isolated). It should not be considered as indicating poor specificity of the $S$. thompson Os-BSA antiserum. 
Confirmatory evidence of the specificity of the $S$. thompson Os-BSA antiserum was obtained from ELISA tests (table I) and COA studies (table V).

Although the detailed structure of the oligosaccharide of $S$. thompson has not yet been determined, it is probably composed of $N$-acetyl-D-glucosamine and D-mannose residues (in a molar ratio of 1:4), with the D-mannose residues joined in 1, 2 linkages and the $\mathrm{N}$-acetyl-D-glucosamine residue substituted at C3 (Lönngren, Svenson and Lindberg, unpublished results). Work is in progress to establish the anomeric configurations. Because mannan structures are of common occurrence in microorganisms, we did not expect to elicit against the mannose-rich oligosaccharide of the $S$. thompson Os-BSA conjugate antibodies of such high specificity as those elicited against the previously described synthetic dideoxyhexopyranosyl 1- $\alpha-3$ mannopyranoside haptens representative of the antigens $\mathrm{O} 2, \mathrm{O} 4, \mathrm{O} 8$ and 09 . Thus, the observation that three of 104 strains of $E$. coli examined were positive in IFL tests was not unexpected, because cross reactions between Salmonella of group $\mathrm{C} 1$ and $E$. coli have been described (Ørskov et al., 1977). In yeasts, a mannan covalently linked to protein represents a principal cell-wall constituent (Ballou, 1976). The mannan has an $\alpha 1$, 6-linked polymannose backbone with branches of $\alpha 1,3$ - and $\alpha 1,2$-linked D-mannose residues. Because the structures of the oligosaccharide of $S$. thompson and the mannan of Candida are similar, the observation that most species of $C$ andida stained with the $S$. thompson Os-BSA antiserum was expected.

The $S$. thompson Os-BSA antiserum was as specific for antigen $\mathrm{O} 7$ as a conventional antiserum, i.e., one prepared by immunisation with heat-killed bacteria and absorbed with five different strains of Salmonella (data not shown). However, because the pentasaccharide contains several different regions, it is likely that antigen O7 contains several antigenic determinants, one of which, if identifiable from further structural studies, may be used as hapten for production of an antiserum wholly specific for salmonellae of serogroup $\mathrm{Cl}$.

We gratefully acknowledge the skilled technical assistance of M. Brandt, B. Larsson and G. Wrangsell. This work was supported by the Swedish Medical Research Council (grant no. 16X-656).

\section{REFERENCES}

Ballou, C. 1976. Structure and biosynthesis of the mannan component of the yeast cell envelope. Adv. microb. Physiol., 14, 93.

Carlsson, H. E., Hurvell, B. ANd Lindberg, A. A. 1976. Enzyme-linked immunosorbent assay (ELISA) for titration of antibodies against Brucella abortus and Yersinia enterocolitica. Acta path. microbiol. scand., 84C, 168.

Cherry, W. B. AND MoOdy, M. D. 1965. Fluorescent-antibody techniques in diagnostic bacteriology. Bact. Rev., 29, 222.

Cherry, W. B., Thomason, B. M., Gladden, J. B., Holsing, N. and Murlin, A. M. 1975. Detection of salmonellae in foodstuffs, feces and water by immunofluorescence. Ann. N.Y. Acad. Sci., 254, 350.

Fuller, N. A. AND STAub, A. M. 1968. Immunochemical studies on Salmonella. 13. Chemical changes appearing on the specific polysaccharide of $S$. cholerae suis $\left(6_{2}, 7\right)$ after its conversion by phage $14(6,7)$. Eur. J. Biochem., 4, 286.

Hellerqvist, C. G., Lindberg, B., Svensson, S., Holme, T. and Lindberg, A. A. 1968. Structural studies on the O-specific side-chains of the cell-wall lipopolysaccharide from Salmonella typhimurium 395 MS. Carbohyd. Res., 8, 43. 
Karlsson, K.-A., Thore, A. AND KudynowsKi, J. 1975. Quantitative studies of direct and indirect immunofluorescent staining of Salmonella bacteria. Acta path. microbiol. scand., 83B, 17

KaufFmanN, F. 1966. The bacteriology of Enterobacteriaceae, Copenhagen, Munksgaard.

KENNE, L. AND LindBERG, B. 1982. Bacterial polysaccharides. In The polysaccharides, edited by G. O. Aspinall, Academic Press, London.

KronvalL, G. 1973. A rapid slide-agglutination method for typing pneumococci by means of specific antibody adsorbed to protein A-containing staphylococci. J. med. Microbiol., 6, 187.

ØrSKov, I., ØRSKOV, F., JANN, B. AND JANN, K. 1977. Serology, chemistry and genetics of O and $\mathrm{K}$ antigens of Escherichia coli. Bact. Rev., 41, 668.

Svenson, S. B. AND Lindberg, A. A. 1979. Coupling of acid labile Salmonella specific oligosaccharides to macromolecular carriers. J. immun. Meth., 25, 323.

SvenUnGSSON, B., JörBECK, H. AND LindBERG, A. A. 1979. Diagnosis of Salmonella infections: specificity of indirect immunofluorescence for rapid identification of Salmonella enteritidis, and usefulness of enzyme-linked immunosorbent assay. J. infect. Dis., 140, 927.

Svenungsson, B. AND LindBerG, A. A. 1977. Synthetic disaccharide-protein antigens for production of specific $\mathrm{O} 4$ and $\mathrm{O} 9$ antisera for immunofluorescence diagnosis of Salmonella. Med. Microbiol. Immun., 163, 1.

SVENUngsson, B. AND LindBerg, A. A. 1978a. Synthetic disaccharide-protein antigen for production of specific $\mathrm{O} 2$ antiserum for immunofluorescence diagnosis of Salmonella. Acta path. microbiol. scand., sect. B 86, 35.

SVEnungsson, B. AND LindBerg, A. A. 1978b. Identification of Salmonella bacteria by co-agglutination, using antibodies against synthetic disaccharide-protein antigens $\mathrm{O} 2, \mathrm{O} 4$ and $\mathrm{O}$ 9, adsorbed to protein A-containing staphylococci. Acta path. microbiol. scand., sect. B. 86, 283.

Svenungsson, B. AND LindBerg, A. A. 1979. Diagnosis of Salmonella bacteria: antibodies against synthetic Salmonella O-antigen 8 for immunofluorescence and co-agglutination using sensitized protein A-containing staphylococci. Acta path. microbiol. scand., sect. B, $87,29$.

Thomason, B. M. and Hebert, G. A. 1974. Evaluation of commercial conjugates for fluorescent antibody detection of Salmonellae. Appl. Microbiol., 27, 862. 